Article

\title{
Effect of Methylmercury Exposure on Bioaccumulation and Nonspecific Immune Respsonses in Hybrid Grouper Epinephelus fuscoguttatus $\times$ Epinephelus lanceolatus
}

\author{
Hsiang-Chieh Chuang ${ }^{1,+}{ }^{,}$Huai-Ting Huang ${ }^{2,+}{ }^{+}$, Novi-Rosmala Dewi ${ }^{2}$, Hsi-Hua Hsiao ${ }^{2}$, Bo-Ying Chen ${ }^{2}$, \\ Zhen-Hao Liao ${ }^{2}$, Meng-Chou Lee ${ }^{2}{ }^{\mathbb{D}}$, Po-Tsang Lee ${ }^{2}$, Yu-Sheng $\mathrm{Wu}^{3}{ }^{3}, \mathrm{Yu}$-Ju Lin ${ }^{4}$ and Fan-Hua Nan ${ }^{2, *}$ \\ 1 Department and Graduate Institute of Aquaculture, National Kaohsiung University of Science and \\ Technology, Kaohsiung City 811213, Taiwan; hcchuang@nkust.edu.tw \\ 2 Department of Aquaculture, National Taiwan Ocean University, Keelung City 20224, Taiwan; \\ twinkleqazwsx784@gmail.com (H.-T.H.); novi.rosmala.d@gmail.com (N.-R.D.); \\ 10933032@mail.ntou.edu.tw (H.-H.H.); joey860812@gmail.com (B.-Y.C.); \\ smallhowhow1234@gmail.com (Z.-H.L.); mengchoulee@mail.ntou.edu.tw (M.-C.L.); \\ leepotsang@mail.ntou.edu.tw (P.-T.L.) \\ 3 Department of Aquaculture, National Pingtung University of Science and Technology, \\ Pingtung County 912301, Taiwan; wuys0313@mail.npust.edu.tw \\ 4 Department of Life Sciences, National Chung Hsing University, Taichung City 402002, Taiwan; \\ yjl@dragon.nchu.edu.tw \\ * Correspondence: fhnan@mail.ntou.edu.tw; Tel.: +886-22462-2192 (ext. 2910) \\ + These authors contributed equally to this work.
}

Citation: Chuang, H.-C.; Huang, H.-T.; Dewi, N.-R.; Hsiao, H.-H.; Chen, B.-Y.; Liao, Z.-H.; Lee, M.-C.; Lee, P.-T.; Wu, Y.-S.; Lin, Y.-J.; et al. Effect of Methylmercury Exposure on Bioaccumulation and Nonspecific Immune Respsonses in Hybrid Grouper Epinephelus fuscoguttatus $\times$ Epinephelus lanceolatus. Animals 2022, 12, 147. https://doi.org/10.3390/ ani12020147

Academic Editor: Ravi Fotedar

Received: 18 November 2021

Accepted: 7 January 2022

Published: 8 January 2022

Publisher's Note: MDPI stays neutral with regard to jurisdictional claims in published maps and institutional affiliations.

Copyright: (C) 2022 by the authors. Licensee MDPI, Basel, Switzerland. This article is an open access article distributed under the terms and conditions of the Creative Commons Attribution (CC BY) license (https:// creativecommons.org/licenses/by/ $4.0 /)$.
Simple Summary: The head kidney was primary organ that accumulated methylmercury in hybrid grouper. Muscle tissue had lower methylmercury content than the head kidney and liver. Nonspecific immune responses and bioaccumulation of methylmercury were linked to hybrid grouper health.

\begin{abstract}
Mercury $(\mathrm{Hg})$ is a dangerous heavy metal that can accumulate in fish and is harmful when consumed by humans. This study investigated the bioaccumulation of mercury in the form of methylmercury (MeHg) and evaluated nonspecific immune responses such as phagocytic activity and superoxide anion $\left(\mathrm{O}_{2}{ }^{-}\right.$) production in hybrid grouper (Epinephelus fuscoguttatus $\times$E. lanceolatus). The hybrid grouper leukocytes were incubated with methylmercury chloride $\left(\mathrm{CH}_{3} \mathrm{HgCl}\right)$ at concentrations of $10-10,000 \mu \mathrm{g} / \mathrm{L}$ to determine cell viability, phagocytic activity, and $\mathrm{O}_{2}{ }^{-}$production in vitro. Subsequently, the grouper were exposed daily to $\mathrm{CH}_{3} \mathrm{HgCl}$ mixed in the experimental diets at concentrations of $0,1,5$, and $10 \mathrm{mg} / \mathrm{kg}$ for 28 days. The bioaccumulation of $\mathrm{MeHg}$ in the liver, head kidney, and muscle tissue was measured, and the phagocytic activity and $\mathrm{O}_{2}{ }^{-}$production were evaluated. In vitro results indicated that cell viability was significantly lower than that of the control group at concentrations $>500 \mu \mathrm{g} / \mathrm{L}$. The phagocytic rate and $\mathrm{O}_{2}{ }^{-}$production at concentrations $>500$ and $>200 \mu \mathrm{g} / \mathrm{L}$, respectively, were significantly lower than those of the control group. The dietary exposure demonstrated that $\mathrm{MeHg}$ accumulated more substantially in the liver and head kidney compared with the muscle tissue in the treatment groups. Moreover, the cumulative concentration significantly increased with higher concentrations and more days of exposure. The phagocytic rate and $\mathrm{O}_{2}{ }^{-}$production in the treatment groups were significantly lower than those in the control group from days 2 and 1, respectively. In conclusion, hybrid grouper accumulated significant $\mathrm{MeHg}$ in the liver and head kidney compared with the muscle tissue, and higher concentrations and more exposure days resulted in decreased cell viability, phagocytic activity, and $\mathrm{O}_{2}{ }^{-}$production.
\end{abstract}

Keywords: hybrid grouper; methylmercury; bioaccumulation; immunity 


\section{Introduction}

Grouper is an important aquaculture species cultivated in Taiwan. As the world's second largest grouper producer, Taiwan's production of approximately 234 tons accounted for $10 \%$ of the world's total grouper production in 2019 [1]. Cultured species are primarily tiger grouper (Epinephelus fuscoguttatus) and giant grouper (E. lanceolatus), which are widely distributed in the Indo-Pacific region [2]. Tiger grouper is a popular cultured marine species in Asia due to its rapid growth rate, and giant grouper, which can reach a maximum weight of $400 \mathrm{~kg}$, is the largest grouper species [3]. A crossbreed of these two species is the hybrid giant tiger grouper, which became popular due to its high survival rate, feeding performance, rapid growth rate, and tolerance of a wide range of rearing parameters $[4,5]$. Grouper aquaculture is mostly conducted in offshore cages; marine culture, which first developed in the 1990s for cobia (Rachycentron canadum), is a current trend in raising giant grouper [6]. However, marine environmental pollution from heavy metals has attracted global attention because such pollution harms fish [7].

Heavy metals such as cadmium $(\mathrm{Cd})$, mercury $(\mathrm{Hg})$, lead $(\mathrm{Pb})$, chromium $(\mathrm{Cr})$, and arsenic (As) are toxic to both humans and animals [8]. Mercury is a toxic heavy metal and has no essential biological function. Commonly, mercury enters the marine environment through natural processes such as volcanic activity and erosion or industrial and agricultural sewage discharge; mercury affects the food chain through fish consumption and can affect human health [9]. Even MeHg is present in very low concentrations in seawater, they are absorbed by algae at the start of the food chain. The algae is then eaten by fish and other higher-level organisms in the food chain. Methylmercury (MeHg) and inorganic $\mathrm{Hg}$ (II) are the most abundant forms of $\mathrm{Hg}$ found in fish [10]. Due to industrial activities, aquatic animals absorb more and more pollutants, including MeHg. Fish can efficiently absorb $\mathrm{MeHg}$ but excrete very slowly. Several studies have focused on the human health risk associated with exposure to toxic metals through fish consumption [10-12]. However, how bioaccumulation and nonspecific immune response affect fish health has been neglected. Few studies have addressed the fish health risk associated with $\mathrm{MeHg}$ toxicity, specifically in terms of physiological responses $[13,14]$.

Fish meal which is made from whole fish or fish related product is one of the common feed ingredients. Fish meal that made from these contaminated fish contains highly MeHg. Grouper culture may be affected by $\mathrm{MeHg}$ pollution of its environment because fish mealcontaining feed is used in the culture system. However, little is known regarding the risk of such pollution to the hybrid grouper. To our knowledge, no studies have focused on the effect of $\mathrm{MeHg}$ toxicity, nonspecific immune responses, and bioaccumulation on the hybrid grouper. The head kidney is a lymphatic organ and produce a lot of leukocytes which are involved in phagocytosis of invading pathogens [15]. Head kidney play a key role in the nonspecific immune response of fish. Fish consumption is the main source of exposure to methylmercury for human, and grouper is an important economic aquatic species in Taiwan. Therefore, it is very important to understand the safety of grouper in food and breeding. In our study, the effect of $\mathrm{MeHg}$ on phagocytic activity and $\mathrm{O}_{2}{ }^{-}$ production of grouper head kidney leukocytes were evaluated in vitro and in vivo. The bioaccumulation of $\mathrm{MeHg}$ in the liver, head kidney, and muscle tissue was measured to determine the accumulation level after dietary exposure.

\section{Materials and Methods}

\subsection{The In Vitro Effect of Methylmercury}

Cell viability and nonspecific immune responses in vitro were evaluated to determine the suitable concentration to use in in vivo experiment. Each in vitro experiment was performed with 3 hybrid groupers ( $200 \pm 24.98 \mathrm{~g}$ ). Hybrid groupers were purchased from local farm in Yilan County, Taiwan. The fish were acclimatized to the laboratory conditions for 2 weeks in tanks $(200 \times 120 \times 70 \mathrm{~cm})$ and fed with a commercial diet (Tairoun Products Co., Ltd., Taiwan) twice daily. The feed contains $45 \%$ crude protein, $8 \%$ crude lipid, $16 \%$ ash, and 3\% crude fibre. All the fish appeared with normal activity, feed intake and without 
injury. The water conditions were maintained as follows: temperature at $27 \pm 1{ }^{\circ} \mathrm{C}$, salinity at $33 \pm 1 \%$, the $\mathrm{pH}$ at $8.2 \pm 0.2$, dissolved oxygen (DO) at $5.5-7.3 \mathrm{mg} / \mathrm{L}$, and a photoperiod of $12 \mathrm{~h}$ of light: $12 \mathrm{~h}$ of dark. Animal experiments were performed according to the guidelines of the Institutional Animal Care and Use Committee at National Taiwan Ocean University (protocol number 105063).

The head kidneys of fish were excised, minced and mixed together. Leukocytes were isolated from the head kidney of the fish using the Percoll density gradient centrifugation method modified from Chang et al. [16]. Two Percoll mixtures were prepared from Percoll (Pharmacia, Piscataway, NJ, USA) and $\mathrm{NaCl}$ (1.5 M, Sigma-Aldrich, St. Louis, MO, USA) at a ratio of 9:1 and HBSS (Hank's balanced salt solution; Gibco, Waltham, MA, USA) at concentrations of $35 \%$ and $50 \%$. The head kidney was placed in a petri dish containing $4 \mathrm{~mL}$ of HBSS. Briefly, the head kidney was shredded with tweezers and filtered through a $100-\mu \mathrm{m}$ nylon mesh (Bio-Rad, Hercules, CA, USA). The filtrate was put into a centrifuge tube filled with $35 \%$ and $50 \%$ Percoll mixtures and centrifuged at $400 \times g, 4{ }^{\circ} \mathrm{C}$, for $10 \mathrm{~min}$. The leukocytes at the interface were collected and subsequently resuspended with HBSS and centrifuged; this procedure was repeated three times. The leukocyte concentration was adjusted to $5 \times 10^{6}$ cells $/ \mathrm{mL}$.

\subsubsection{Cell Viability}

Cell viability was evaluated using an MTT assay by following the method of DomínguezBorbor et al. [17] with modifications. Briefly, $100 \mu \mathrm{L}$ of a leukocyte suspension was pipetted into each plate of a 96-well microplate, which was then centrifuged at $400 \times g, 4{ }^{\circ} \mathrm{C}$, for $10 \mathrm{~min}$. The supernatant was removed, and $100 \mu \mathrm{L}$ of $\mathrm{CH}_{3} \mathrm{HgCl}$ in $\mathrm{HBSS}$ at concentrations of $0,10,50,70,100,200,500,1000,5000$, and 10,000 $\mu \mathrm{g} / \mathrm{L}$ was added into each well in triplicate. The cells were incubated for $30 \mathrm{~min}$. Subsequently, the supernatant was removed, and $100 \mu \mathrm{L}$ of MTT solution was added into each well in the dark and incubated for $4 \mathrm{~h}$ at room temperature. After removing the supernatant, $100 \mu \mathrm{L}$ of dimethyl sulfoxide (DMSO; Honeywell, Charlotte, NC, USA) was added and the resultant mixture was vortexed for $10 \mathrm{~min}$. Absorbance was measured using an ELISA reader (VersaMax Tunable Microplate Reader; Molecular Devices, Sunnyvale, CA, USA) at a wavelength of $570 \mathrm{~nm}$. The cell viability percentage was calculated using the following equation:

$$
\text { Cell viability }(\%)=\frac{O D \text { of treatment average }}{\text { OD of control average }} \times 100 \%
$$

\subsubsection{Phagocytic Activity Assay}

The phagocytic activity in vitro was evaluated after preincubating with $\mathrm{CH}_{3} \mathrm{HgCl}$ at concentrations of $0,50,100,200,500,1000$, and $5000 \mu \mathrm{g} / \mathrm{L}$ for $30 \mathrm{~min}$. Phagocytic activity was evaluated using a method modified from Yue et al. [18]. Briefly, $100 \mu \mathrm{L}$ of leukocyte suspension was dropped on the cover glass and incubated for $1 \mathrm{~h}$ at room temperature. The supernatant was removed, and $100 \mu \mathrm{L}$ of latex beads suspension $(0.8 \mu \mathrm{m}$, $5 \times 10^{7}$ beads $/ \mathrm{mL}$; Sigma-Aldrich, St. Louis, MO, USA) was added and incubated for 30 min at room temperature. The non-phagocytosed beads were removed with HBSS and fixated with methanol for $5 \mathrm{~min}$. Subsequently, the surface was washed with $\mathrm{ddH}_{2} \mathrm{O}$, stained with Giemsa for 20 min, decolorized with $\mathrm{ddH}_{2} \mathrm{O}$, air-dried, and observed under a light microscope (Olympus BX41 Phase Contrast; Olympus, Tokyo, Japan). The phagocytic cells were counted, and the phagocytic rate and phagocytic index were calculated using the following equations:

$$
\begin{gathered}
\text { Phagocytic rate }(\%)=\frac{\text { Total phagocytic cells }}{\text { Total cells }} \times 100 \\
\text { Phagocytic index }=\frac{\text { Beads in phagocytic cells }}{\text { Total phagocytic cells }}
\end{gathered}
$$




\subsubsection{Superoxide Anion $\left(\mathrm{O}_{2}{ }^{-}\right)$Production Assay}

The $\mathrm{O}_{2}{ }^{-}$production rate was evaluated using the nitro blue tetrazolium reduction method modified from Rotllant et al. [19]. Briefly, $100 \mu \mathrm{L}$ of a leukocyte suspension was pipetted into each plate of a 96-well microplate, which was then centrifuged at $400 \times g$, $4{ }^{\circ} \mathrm{C}$, for $10 \mathrm{~min}$. The supernatant was removed, and $100 \mu \mathrm{L}$ of $\mathrm{CH}_{3} \mathrm{HgCl}$ in $\mathrm{HBSS}$ at concentrations of $0,50,100,200,500,1000$, and $5000 \mu \mathrm{g} / \mathrm{L}$ was added into each well in triplicate (For in vivo experminent, the step of incubation was skipped). After $30 \mathrm{~min}$ incubation, the supernatant was removed, and $100 \mu \mathrm{L}$ of zymosan (Sigma-Aldrich, St. Louis, MO, USA) for the sample and $100 \mu \mathrm{L}$ of HBSS for the background were added; the solution was incubated for $30 \mathrm{~min}$ at room temperature. The supernatant was removed, $100 \mu \mathrm{L}$ of $0.3 \%$ NBT solution was added, and the solution was incubated for $30 \mathrm{~min}$ at room temperature. The supernatant was removed and washed with methanol; this procedure was repeated three times. After the supernatant was air-dried, $120 \mu \mathrm{L}$ of $\mathrm{KOH}$ (2M) and $140 \mu \mathrm{L}$ of DMSO were added, and the absorbance was measured using an ELISA reader at a wavelength of $630 \mathrm{~nm}$. The $\mathrm{O}_{2}{ }^{-}$production rate was calculated using the following equation:

$$
\mathrm{O}_{2}{ }^{-} \text {production rate }(\%)=\frac{\text { OD of sample }- \text { OD of background }}{\text { OD of background }} \times 100
$$

\subsection{The In Vivo Effect of Methylmercury}

\subsubsection{Dietary Exposure of Methylmercury}

For experimental diets, the commercial feed was crushed and divided into four groups. Group 1 (control group) was not mixed with others. Group 2-4 were mixed with 1, 5 and $10 \mathrm{mg}$ methylmercury chloride standard solution $\left(\mathrm{CH}_{3} \mathrm{HgCl}\right.$; purity $99.6 \%$; SigmaAldrich, St. Louis, MO, USA) per kg. Subsequently, the feed were pelleted through a miner; the resulting pellets were dried in an oven at $40{ }^{\circ} \mathrm{C}$ and stored in a dark sealed bin. The concentration of MeHg in each feed was confirmed using high performance liquid chromatography-inductively coupled plasma-mass spectrometry (HPLC-ICP-MS).

A total of 87 hybrid groupers $(200 \pm 24.98 \mathrm{~g})$ were randomly distributed into four groups. Each group included 21 fish maintained in a $270 \mathrm{~L}$ tank $(90 \times 60 \times 50 \mathrm{~cm})$ with flow through system, and water exchange was $50 \%$ per day. The fish was fed twice daily with the experimental diets at $3 \%$ body mass for 28 days. Three fish from each group were sampled on days $0,1,2,7,14$, and 28 to determine immune parameters of head kidney leukocytes and bioaccumulation of $\mathrm{MeHg}$ in liver, head kidney, and muscle. The phagocytic activity and $\mathrm{O}_{2}{ }^{-}$production were measured following the methods described in Sections 2.1.2 and 2.1.3 using leukocytes isolated from the head kidney. The samples of bioaccumulation were from the same fish which from the nonspecific immune samples.

\subsubsection{Measurement of Methylmercury Bioaccumulation}

Bioaccumulation of $\mathrm{MeHg}$ in the liver, head kidney, and muscle tissue was determined using the high performance liquid chromatography -inductively coupled plasmamass spectrometry (HPLC-ICP-MS) method. Each group has three replications. Briefly, the sample was minced with a homogenizer, and $0.5 \mathrm{~g}$ of the sample was put in a flask, mixed with extraction solvent (10 g of L-cysteine hydrochloride in $1000 \mathrm{~mL}$ of deionized water), and extracted by shaking vigorously for $10 \mathrm{~s}$, followed by ultrasonic shaking in a $60{ }^{\circ} \mathrm{C}$ water bath for $40 \mathrm{~min}$. The volume was adjusted to $50 \mathrm{~mL}$ at room temperature and filtered through a $0.2-\mu \mathrm{m}$ filter membrane (Biofil, Indore, MP, India). Extraction solvent (treated equally) was used as a blank solution.

HPLC-ICP-MS was performed using an inductively coupled plasma mass spectrometer (Thermo X series II; Thermo Fisher Scientific, Waltham, MA, USA) equipped with a P680 HPLC pump (Dionex, Sunnyvale, CA, USA). HPLC separation was performed in a Synergi Hydro-RP $80 \AA$ A C18 column $(150 \times 4.6 \mathrm{~mm}$ i.d., 4.0- $\mu \mathrm{m}$ particle size; Phenomenex, Torrance, CA, USA) with a mobile phase of L-cysteine and L-cysteine hydrochloride ( $1 \mathrm{~g}$ 
each, dissolved in $1000 \mathrm{~mL}$ of deionized water) at a flow rate of $1.0 \mathrm{~mL} / \mathrm{min}$ at $25^{\circ} \mathrm{C}$. The concentration of $\mathrm{MeHg}$ in each sample was confirmed using HPLC-ICP-MS and eluted with the mobile phase for $5 \mathrm{~min}$. Standard solutions over a range of $\mathrm{MeHg}$ concentrations (0.4-10 $\mu \mathrm{g} / \mathrm{L})$ spiked with Rhodium $(10 \mathrm{ppb})$ was used to generate a calibration curve $\left(r^{2}=0.9999\right)$. The analytical procedure was validated by a matrix spike and $\mathrm{MeHg}$ recovery rate was found to be more than $95 \%$. The reproducibility CV (coefficient of variation) was $2.07 \%$. The concentration of $\mathrm{MeHg}$ in the samples was calculated using the following equation:

$$
\operatorname{MeHg}(\mathrm{ppm})=\frac{\left(C-C_{0}\right) \times V}{W \times 1000}
$$

$C$ : Concentration of methylmercury in the test solution $\left(\mathrm{ng} \mathrm{mL} \mathrm{mL}^{-1}\right)$

$\mathrm{C}_{0}$ : Concentration of $\mathrm{MeHg}$ in the blank solution $\left(\mathrm{ng} \mathrm{\textrm {mL } ^ { - 1 } )}\right.$

$V$ : Final volume of the sample $(\mathrm{mL})$

$W$ : Weight of the sample $(\mathrm{g})$

\subsection{Statistical Analysis}

Each experiment was conducted in triplicates and data was shown as mean \pm SD (standard deviation). One-way ANOVA and Tukey' test were performed to compare the differences between groups at indicated time point or between different time points in a group Statistical Analysis Software version 9.4 (SAS, Cary, NC, USA). Two-way multivariate analysis of variance (MANOVA) was used to analyse the effects of concentrations and days of exposure. Significant differences among data were further analyzed using Tukey's honestly significant differences procedure with $p$ values $<0.05$ considered significant.

\section{Results}

\subsection{Effect of Methylmercury on Cell Viability In Vitro}

The cell viability values at concentrations of $10,50,70,100$, and $200 \mu \mathrm{g} / \mathrm{L}$ were $>95 \%$ and had no significant differences compared with the control group (Figure 1). Conversely, the cell viability values at concentrations of 500,1000,5000, and 10,000 $\mathrm{\mu g} / \mathrm{L}$ decreased by $86 \%, 82 \%, 39 \%$, and $32 \%$, respectively, and had significant differences compared with the control group $(p<0.05)$.

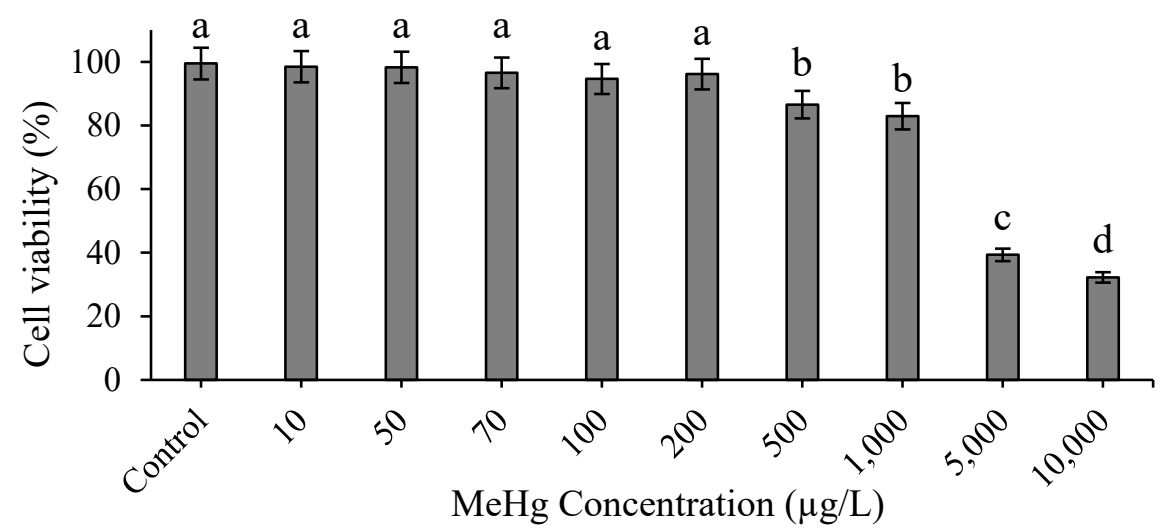

Figure 1. Cell viability of hybrid grouper leukocytes after in vitro incubation with various concentrations of methylmercury for $30 \mathrm{~min}$. One-way ANOVA and Tukey' test were performed to compare the differences between groups. Values are presented as mean $\pm \operatorname{SD}(n=3)$. Significant differences $(p<0.05)$ between treatment groups are indicated by different letters above the bars.

\subsection{Effect of Methylmercury on Nonspecific Immune Responses In Vitro}

The phagocytic rate indicated no significant differences at concentrations of 50, 100, or $200 \mu \mathrm{g} / \mathrm{L}$, whereas at concentrations of 500,1000, and $5000 \mu \mathrm{g} / \mathrm{L}$, the rate indicated significant differences compared with the control group $(p<0.05$; Figure $2 \mathrm{~A})$. Moreover, the 
phagocytic index indicated no significant difference at all concentrations compared with the control group (Figure 2B). Additionally, the $\mathrm{O}_{2}{ }^{-}$production rate had no significant differences at concentrations of 50 and $100 \mu \mathrm{g} / \mathrm{L}$ compared with the control group $(p>0.05$; Figure 3). There are significant differences at concentrations of 200, 500, 1000, and $5000 \mu \mathrm{g} / \mathrm{L}$ compared with the control group $(p<0.05$; Figure 3$)$.
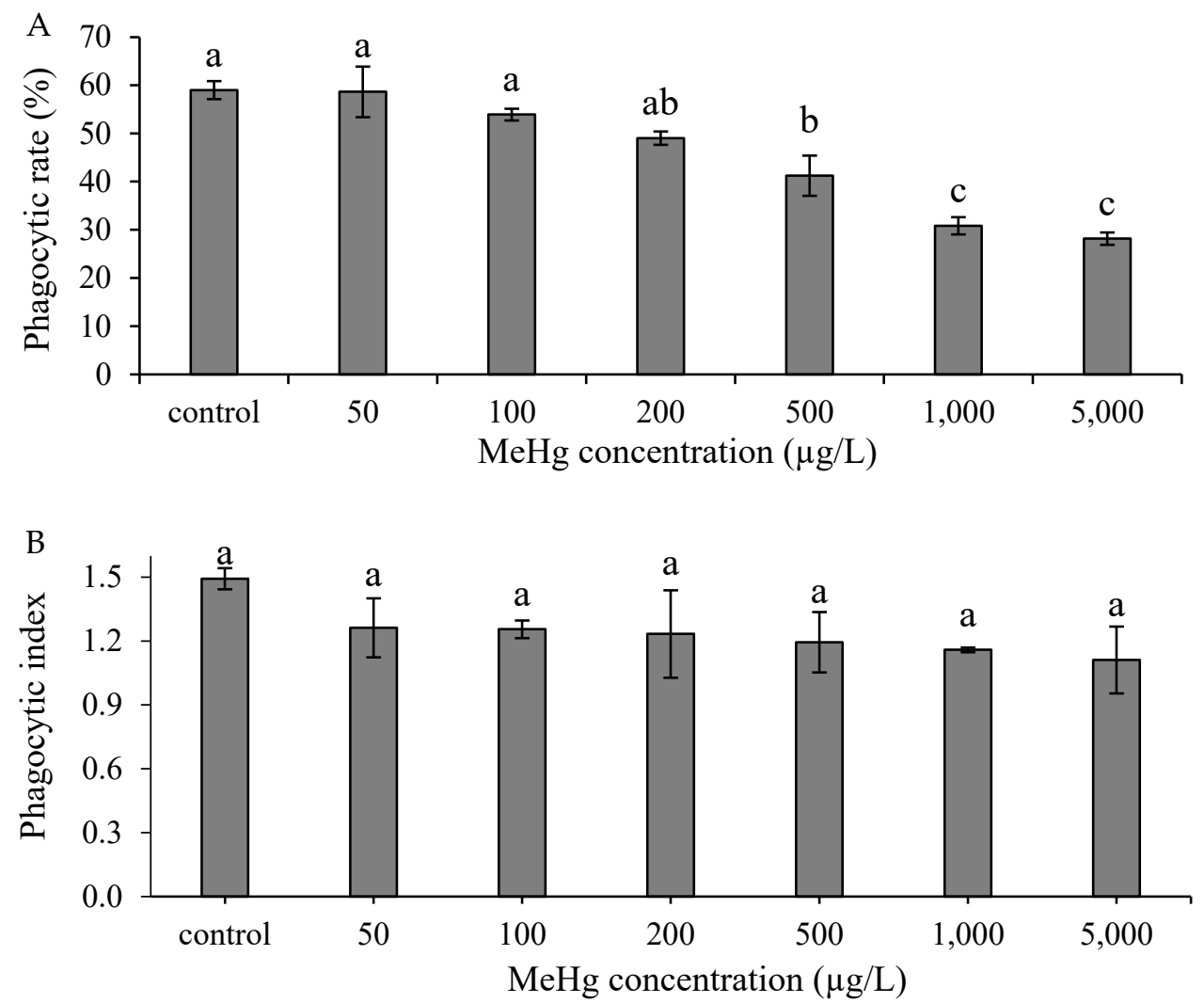

Figure 2. Phagocytic rate (A) and phagocytic index (B) of hybrid grouper leukocytes after in vitro incubation with various concentrations of methylmercury for $30 \mathrm{~min}$. One-way ANOVA and Tukey' test were performed to compare the differences between groups. Values are presented as mean \pm SD $(n=3)$. Significant differences $(p<0.05)$ between treatment groups are indicated by different letters above the bars.

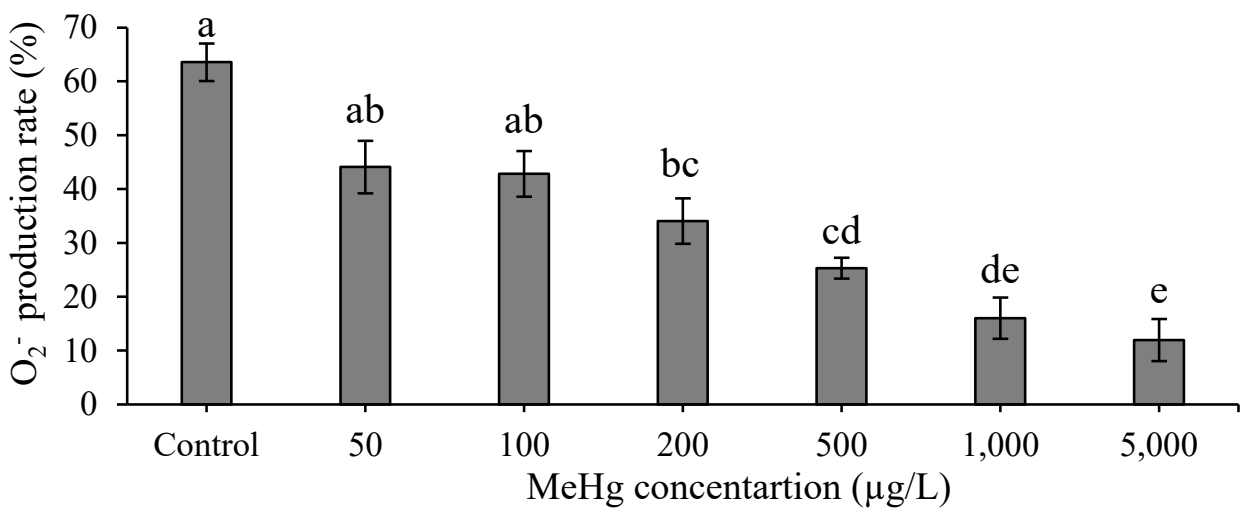

Figure 3. Superoxide anion production rate of hybrid grouper leukocytes after in vitro incubation with various concentrations of methylmercury for $30 \mathrm{~min}$. One-way ANOVA and Tukey' test were performed to compare the differences between groups. Values are presented as mean $\pm \mathrm{SD}(n=3)$. Significant differences $(p<0.05)$ among treatment groups are indicated by different letters above the bars. 


\subsection{Effect of Methylmercury Dietary Exposure on Nonspecific Immune Responses}

Hybrid groupers were exposed daily to $\mathrm{CH}_{3} \mathrm{HgCl}$ mixed in their diets at various concentrations. The phagocytic rate and phagocytic index demonstrated a significant decrease in all treatment groups compared with the control group from day $2(p<0.05$; Figure 4). On days 14 and 28 , the phagocytic rate of the $10 \mathrm{mg} / \mathrm{kg}$ group was significantly different between the treatment groups $(p<0.05)$. Moreover, the $10 \mathrm{mg} / \mathrm{kg}$ group had the lowest phagocytic rate and phagocytic index among the treatment groups during the study. In brief, the phagocytic rate and phagocytic index gradually decreased with increased concentration and more days of exposure to $\mathrm{CH}_{3} \mathrm{HgCl}$.

A

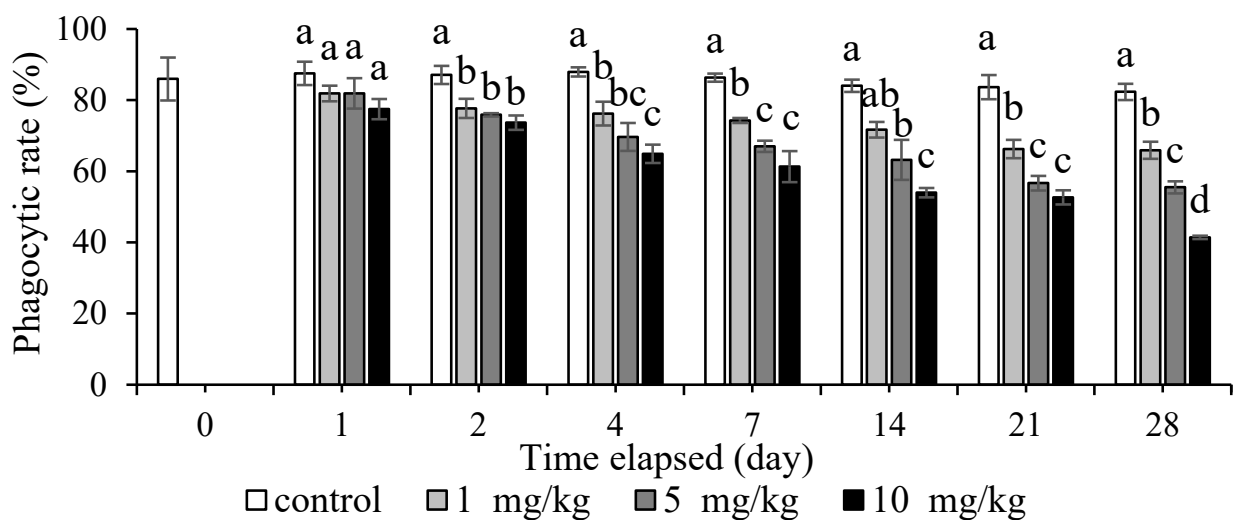

B

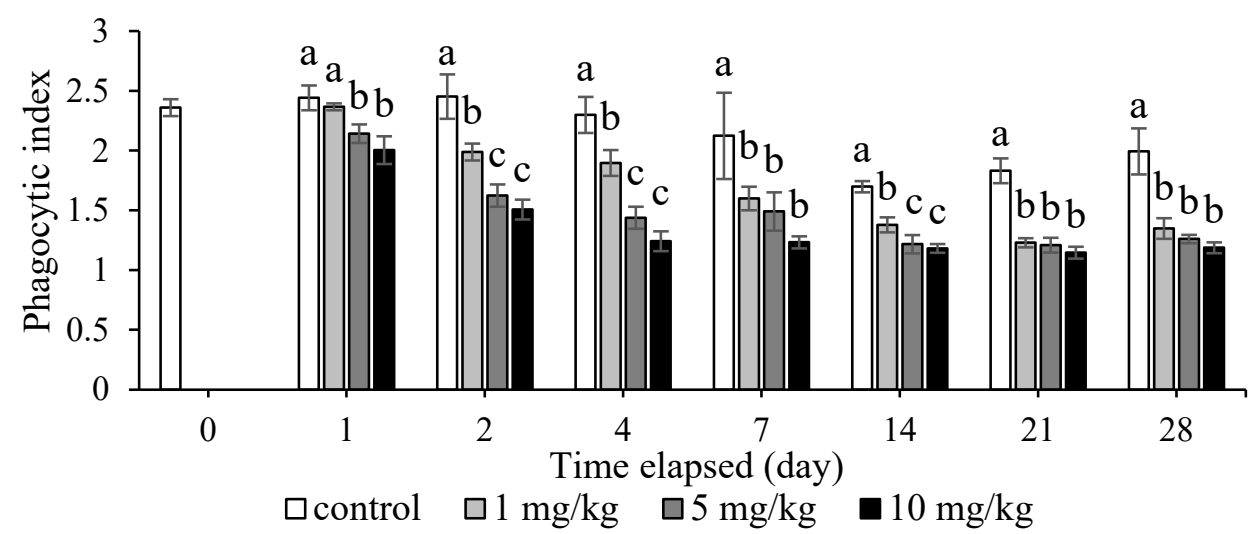

Figure 4. Phagocytic rate (A) and phagocytic index (B) of hybrid grouper fed with various concentrations of methylmercury for 28 days. One-way ANOVA and Tukey' test were performed to compare the differences between groups at indicated time point. Values are presented as mean $\pm \mathrm{SD}(n=3)$. Significant differences $(p<0.05)$ between treatment groups are indicated by different letters above the bars.

The $\mathrm{O}_{2}{ }^{-}$production rate significantly decreased in all treatment groups compared with the control group from day 1 ( $p<0.05$; Figure 5$)$. On days 1 and 2 , no significant differences between the treatment groups were indicated. A significant difference between the treatment groups was observed on day $7(p<0.05)$; the $10 \mathrm{mg} / \mathrm{kg}$ group had the lowest $\mathrm{O}_{2}{ }^{-}$production rate of the treatment groups. In brief, the $\mathrm{O}_{2}{ }^{-}$production rate gradually decreased with increased concentration and more days of exposure to $\mathrm{CH}_{3} \mathrm{HgCl}$. 


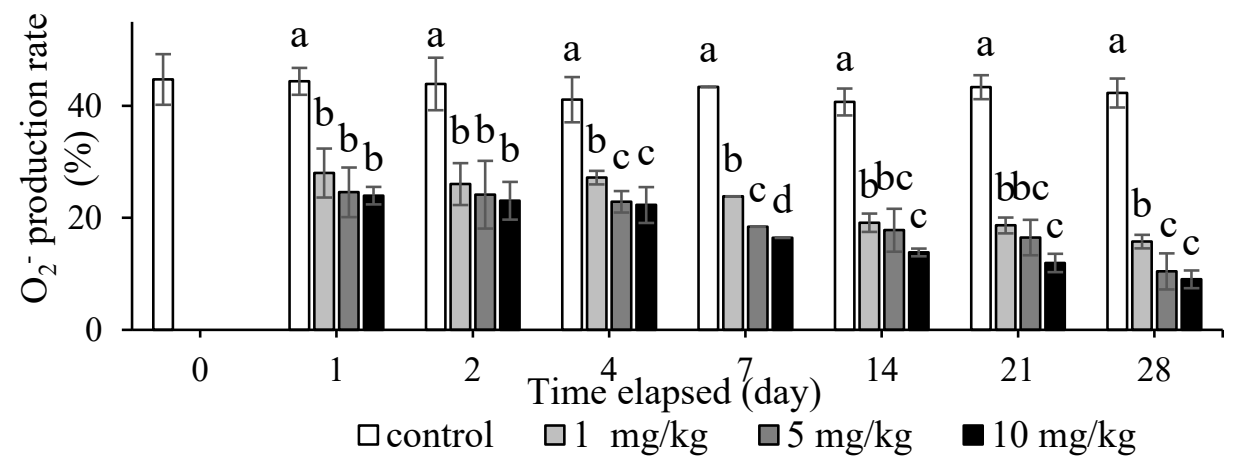

Figure 5. Superoxide anion production rate of hybrid grouper fed with various concentrations of methylmercury for 28 days. One-way ANOVA and Tukey' test were performed to compare the differences between groups at indicated time point. Values are presented as mean $\pm \operatorname{SD}(n=3)$. Significant differences $(p<0.05)$ between treatment groups are indicated by different letters above the bars.

\subsection{Level of Methylmercury Bioaccumulation}

The methylmercury content in the muscle tissue, liver and head kidney was analyzed using HPLC-ICP-MS (Tables 1-4). For muscle tissue (Table 1), the accumulation of the 1,5 , and $10 \mathrm{mg} \mathrm{kg}^{-1}$ treatment group was significantly higher $(p<0.05)$ on day 28 $\left(224.60 \pm 33.87,427.50 \pm 94.02\right.$, and $1213.17 \pm 192.08 \mu \mathrm{g} \mathrm{kg}^{-1}$, respectively) compared with the accumulation on days 1, 4, 7, 14, and 21 (Table 1). On day 1 , the $10 \mathrm{mg} \mathrm{kg}^{-1}$ treatment group was significantly different from the other treatment groups and the control group $(p<0.05)$. On day 4 , the 5 and $10 \mathrm{mg} \mathrm{kg}^{-1}$ treatment groups significantly differed from the control group $(p<0.05)$. On day 7 , a significant difference between the $10 \mathrm{mg} \mathrm{kg}^{-1}$ treatment group and the control group was indicated $(p<0.05)$. On day 14 , significant differences between the 5 and $10 \mathrm{mg} \mathrm{kg}^{-1}$ treatment groups and the control group were indicated $(p<0.05)$. On days 21 and 28, all treatment groups were significantly different compared with the control group $(p<0.05)$. On day 28, significant differences between the three treatment groups were also indicated $(p<0.05)$.

Table 1. Bioaccumulation of methylmercury $(\mu \mathrm{g} / \mathrm{kg})$ in muscle tissue of hybrid grouper fed with various concentrations of methylmercury for 28 days.

\begin{tabular}{|c|c|c|c|c|c|c|c|}
\hline \multirow{2}{*}{$\begin{array}{l}\text { Dose } \\
\text { (mg/kg) }\end{array}$} & \multicolumn{7}{|c|}{ Time Elapsed (Day) } \\
\hline & 0 & 1 & 4 & 7 & 14 & 21 & 28 \\
\hline Control & $40.56 \pm 3.10^{\mathrm{B}}$ & $33.73 \pm 2.75_{b} \mathrm{CD}$ & $25.40 \pm 1.07_{b}{ }^{D}$ & $47.37 \pm 3.09 \mathrm{~b}^{\mathrm{A}}$ & $33.17 \pm 1.89_{C}{ }_{C}^{C D}$ & $28.37 \pm 0.05 c^{D}$ & $39.83 \pm 0.83 \mathrm{~d}^{\mathrm{BC}}$ \\
\hline $1 \mathrm{mg} / \mathrm{kg}$ & & $38.57 \pm 2.25_{b^{B}}$ & $31.90 \pm 3.09 \mathrm{ab}^{\mathrm{B}}$ & $76.57 \pm 9.90_{a b}{ }^{B}$ & $71.40 \pm 6.14_{b}{ }^{B}$ & $71.50 \pm 6.33_{b^{B}}$ & $224.60 \pm 33.87_{c^{A}}{ }^{\mathrm{A}}$ \\
\hline $5 \mathrm{mg} / \mathrm{kg}$ & & $33.13 \pm 1.76_{b^{B}}$ & $50.00 \pm 5.83 \mathrm{a}^{\mathrm{B}}$ & $89.17 \pm 6.97{ }_{a b}{ }^{B}$ & $116.53 \pm 2.91 a^{B}$ & $154.60 \pm 32.74_{\mathrm{ab}}{ }^{\mathrm{B}}$ & $427.50 \pm 94.02 \mathrm{~b}^{\mathrm{A}}$ \\
\hline $10 \mathrm{mg} / \mathrm{kg}$ & & $42.07 \pm 2.46_{a^{B}}$ & $46.27 \pm 9.71_{a^{B}}$ & $130.27 \pm 34.72 \mathrm{a}^{\mathrm{B}}$ & $130.07 \pm 14.08_{a^{B}}$ & $177.80 \pm 72.07_{a^{B}}$ & $1213.17 \pm 192.08_{a^{A}}{ }^{A}$ \\
\hline
\end{tabular}

Values are shown as the mean $\pm \mathrm{SD}(n=3)$. One-way ANOVA and Tukey' test were performed to compare the differences between groups at indicated time point or between different time points in a group.; Means in the same row with different letters $(\mathrm{A}, \mathrm{B}, \mathrm{C}, \mathrm{D})$ are significantly different $(p<0.05)$; Means in the same column with different letters $(\mathrm{a}, \mathrm{b}, \mathrm{c}, \mathrm{d})$ are significantly different $(p<0.05)$.

Regarding the liver (Table 2), the bioaccumulation of the 1,5, and $10 \mathrm{mg} \mathrm{kg}^{-1}$ treatment groups was significantly higher $(p<0.05)$ on day $28(478.73 \pm 51.69,1136.67 \pm 91.59$, and $3428.00 \pm 346.34 \mu \mathrm{g} \mathrm{kg}^{-1}$, respectively) compared with that on day 1, 4, 7, 14, and 21 (Table 2). On days 1 and 4, no significant difference between the treatment groups and the control group was indicated $(p>0.05)$. On day 7 , a significant difference between the $10 \mathrm{mg} \mathrm{kg}^{-1}$ treatment group and the control group was indicated $(p<0.05)$. On days 14,21 , and 28, all of the treatment groups had significant differences compared with the control group $(p<0.05)$. Moreover, on day 28, significant differences between the three treatment groups were indicated $(p<0.05)$. 
Table 2. Bioaccumulation of methylmercury $(\mu \mathrm{g} / \mathrm{kg})$ in liver of hybrid grouper fed with various concentrations of methylmercury for 28 days.

\begin{tabular}{|c|c|c|c|c|c|c|c|}
\hline \multirow{2}{*}{$\begin{array}{c}\text { Dose } \\
(\mathrm{mg} / \mathrm{kg})\end{array}$} & \multicolumn{7}{|c|}{ Time Elapsed (Day) } \\
\hline & 0 & 1 & 4 & 7 & 14 & 21 & 28 \\
\hline Control & $19.4 \pm 0.75^{\mathrm{B}}$ & $28.00 \pm 1.02 \mathrm{a}^{\mathrm{B}}$ & $24.43 \pm 5.83 \mathrm{a}^{\mathrm{B}}$ & $34.23 \pm 0.68_{\mathrm{b}}{ }^{\mathrm{A}}$ & $18.77 \pm 4.46_{c}{ }^{B}$ & $26.13 \pm 2.19 c^{B}$ & $29.57 \pm 1.23 \mathrm{~d}^{\mathrm{B}}$ \\
\hline $1 \mathrm{mg} / \mathrm{kg}$ & & $33.30 \pm 1.40{ }_{\mathrm{a}}^{\mathrm{C}}$ & $31.63 \pm 9.97 \mathrm{a}^{\mathrm{C}}$ & $\begin{array}{c}133.13 \pm \\
\mathrm{ab}\end{array}$ & $159.63 \pm 18.35_{\mathrm{b}}^{\mathrm{B}}$ & $218.57 \pm 11.48_{b}{ }^{B}$ & $478.73 \pm 51.69 \mathrm{c}^{\mathrm{A}}$ \\
\hline $5 \mathrm{mg} / \mathrm{kg}$ & & $30.23 \pm 1.52{ }_{\mathrm{a}}{ }^{\mathrm{C}}$ & $53.83 \pm 26.44{ }_{a}{ }^{C}$ & 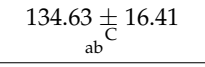 & $408.00 \pm 43.29 \mathrm{a}^{\mathrm{B}}$ & $374.63 \pm 76.46_{a b}{ }^{B}$ & $1136.67 \pm 91.59_{b}{ }^{A}$ \\
\hline $10 \mathrm{mg} / \mathrm{kg}$ & & $51.63 \pm 20.74 \mathrm{a}^{\mathrm{B}}$ & $93.53 \pm 38.30 a^{B}$ & $249.50 \pm 97.37_{a^{B}}$ & $458.77 \pm 90.92 \mathrm{a}^{\mathrm{B}}$ & $331.67 \pm 44.73_{a^{B}}$ & $3428.0 \pm 346.34 \mathrm{a}^{\mathrm{A}}$ \\
\hline & & $\begin{array}{l}\text { Values are sh } \\
\text { differences be } \\
\text { row with diff } \\
\text { letters }(a, b, c, c\end{array}$ & $\begin{array}{l}\mathrm{n} \text { as the mean } \\
\text { een groups at in } \\
n \text { letters (A, B, C } \\
\text { re significantly }\end{array}$ & $\begin{array}{l}\mathrm{D}(n=3) . \text { One- } \\
\text { ated time point } \\
\text { re significantly } \\
\text { erent }(p<0.05) \text {. }\end{array}$ & $\begin{array}{l}\text { ANOVA and } \mathrm{T} \\
\text { petween different } \\
\text { ferent }(p<0.05)\end{array}$ & $\begin{array}{l}\text { ey' test were perf } \\
\text { me points in a gro } \\
\text { eans in the same }\end{array}$ & $\begin{array}{l}\text { ned to compare th } \\
\text { Means in the san } \\
\text { umn with differe }\end{array}$ \\
\hline
\end{tabular}

Table 3. Bioaccumulation of methylmercury $(\mu \mathrm{g} / \mathrm{kg})$ in head kidney of hybrid grouper fed with various concentrations of methylmercury for 28 days.

\begin{tabular}{|c|c|c|c|c|c|c|c|}
\hline \multirow{2}{*}{$\begin{array}{c}\text { Dose } \\
(\mathrm{mg} / \mathrm{kg})\end{array}$} & \multicolumn{7}{|c|}{ Time Elapsed (Day) } \\
\hline & 0 & 1 & 4 & 7 & 14 & 21 & 28 \\
\hline Control & $18.77 \pm 3.51^{\mathrm{A}}$ & $10.83 \pm 0.54{ }_{a}{ }^{B}$ & $6.17 \pm 1.05_{c}{ }^{B}$ & $22.93 \pm 0.40_{\mathrm{b}}{ }^{\mathrm{A}}$ & $5.43 \pm 1.25{ }_{c}{ }^{B}$ & $10.60 \pm 0.28 c^{B}$ & $17.87 \pm 1.51 \mathrm{~d}^{\mathrm{A}}$ \\
\hline $1 \mathrm{mg} / \mathrm{kg}$ & & $13.23 \pm 2.41_{\mathrm{a}}^{\mathrm{C}}$ & $23.87 \pm 6.33_{\mathrm{b}}{ }^{\mathrm{C}}$ & $128.77 \pm 56.34_{a^{B}}$ & $149.33 \pm 19.01 b^{B}$ & $211.63 \pm 16.16_{b}^{B}$ & $433.97 \pm 14.48_{c}{ }^{\mathrm{A}}$ \\
\hline $5 \mathrm{mg} / \mathrm{kg}$ & & $21.10 \pm 1.61_{\mathrm{a}}^{\mathrm{D}}$ & $56.93 \pm 13.70{ }_{a}{ }^{C D}$ & $\underset{\mathrm{a}}{189.13_{\mathrm{CD}} \pm} 35.01$ & $\underset{\mathrm{a}}{266.00 \underset{\mathrm{BC}}{ \pm}} 29.12$ & $336.57 \pm 50.95_{a^{B}}$ & $1063.67 \pm 159.79 \mathrm{~b}^{\mathrm{A}}$ \\
\hline $10 \mathrm{mg} / \mathrm{kg}$ & & $36.30 \pm 19.04 a^{\mathrm{B}}$ & $103.87 \pm 59.37_{a^{B}}$ & $222.70 \pm 79.69_{a^{B}}$ & $316.73 \pm 53.88_{a^{B}}$ & $252.93 \pm 75.78_{a^{B}}$ & $4037.67 \pm 287.47_{a^{A}}{ }^{\mathrm{A}}$ \\
\hline
\end{tabular}

One-way ANOVA and Tukey' test were performed to compare the differences between groups. Values are shown as the mean $\pm \mathrm{SD}(n=3)$; Means in the same row with different letters $\left({ }^{\mathrm{A}}, \mathrm{B}, \mathrm{C}, \mathrm{D}\right)$ are significantly different $(p<0.05)$; Means in the same column with different letters $(\mathrm{a}, \mathrm{b}, \mathrm{c}, \mathrm{d})$ are significantly different $(p<0.05)$.

Table 4. Bioaccumulation of methylmercury $(\mu \mathrm{g} / \mathrm{kg})$ in muscles, liver and kidney of hybrid grouper fed with various concentrations of methylmercury for 28 days.

\begin{tabular}{|c|c|c|c|c|c|c|c|c|}
\hline \multirow{2}{*}{ Tissue } & \multirow{2}{*}{$\begin{array}{l}\text { Dose } \\
(\mathrm{mg} / \mathrm{kg})\end{array}$} & \multicolumn{7}{|c|}{ Time Elapsed (Day) } \\
\hline & & 0 & 1 & 4 & 7 & 14 & 21 & 28 \\
\hline \multirow{4}{*}{ Muscle } & Control & $40.56 \pm 3.10^{a}$ & $33.73 \underset{\mathrm{abc}}{ \pm} 2.75$ & $25.40 \pm 1.07^{\mathrm{ab}}$ & $47.37 \pm 3.09^{\mathrm{cd}}$ & $33.17 \pm 1.89$ ef & $28.37 \pm 0.05^{\mathrm{fg}}$ & $39.83 \pm 0.83^{\mathrm{d}}$ \\
\hline & $1 \mathrm{mg} / \mathrm{kg}$ & & $38.57 \underset{\mathrm{abc}}{ \pm} 2.25$ & $31.90 \pm 3.09^{a b}$ & $76.57 \underset{\text { bcd }}{ \pm} 9.90$ & $71.40 \pm 6.14^{\text {ef }}$ & $71.50 \pm 6.33^{\mathrm{efg}}$ & $224.60 \pm 33.87^{d}$ \\
\hline & $5 \mathrm{mg} / \mathrm{kg}$ & & $33.13 \underset{\mathrm{abc}}{ \pm} 1.76$ & $50.00 \pm 5.83^{\mathrm{ab}}$ & $89.17 \underset{\text { bcd }}{ \pm} 6.97$ & $116.53 \pm 2.91^{\text {ef }}$ & 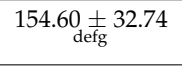 & $427.50 \pm 94.02^{\mathrm{d}}$ \\
\hline & $10 \mathrm{mg} / \mathrm{kg}$ & & $42.07 \pm 2.46^{\mathrm{ab}}$ & $46.27 \pm 9.71^{\mathrm{ab}}$ & $\underset{\mathrm{abcd}}{130.27 \pm} 34.72$ & $130.07 \pm 14.08^{\text {ef }}$ & $177.80 \underset{\text { cdef }}{ \pm} 72.07$ & $1213.17 \pm 192.08^{c}$ \\
\hline \multirow{4}{*}{ Liver } & Control & $19.4 \pm 0.75^{\mathrm{b}}$ & $28.00 \pm 1.02$ & $24.43 \pm 5.83^{\mathrm{ab}}$ & $34.23 \pm 0.68^{\mathrm{cd}}$ & $18.77 \pm 4.46^{\mathrm{f}}$ & $26.13 \pm 2.19 \mathrm{fg}$ & $29.57 \pm 1.23^{\mathrm{d}}$ \\
\hline & $1 \mathrm{mg} / \mathrm{kg}$ & & $33.30 \underset{\mathrm{abc}}{ \pm} 1.40$ & $31.63 \pm 9.97^{\mathrm{ab}}$ & $\underset{\mathrm{abcd}}{133.13 \pm} 32.26$ & $159.63 \pm 18.35$ de & $\underset{\text { abcde }}{218.57 \pm 11.48}$ & $478.73 \pm 51.69^{d}$ \\
\hline & $5 \mathrm{mg} / \mathrm{kg}$ & & $30.23 \underset{\mathrm{abc}}{ \pm} 1.52$ & $53.83 \underset{\mathrm{ab}}{ \pm} 26.44$ & $\underset{\mathrm{abcd}}{134.63 \pm 16.41}$ & $408.00 \pm 43.29^{\mathrm{ab}}$ & $374.63 \pm 76.46$ & $1136.67 \pm 91.59^{c}$ \\
\hline & $10 \mathrm{mg} / \mathrm{kg}$ & & $51.63 \pm 20.74^{a}$ & $93.53 \pm 38.30^{\mathrm{a}}$ & $249.50 \pm 97.37$ & $458.77 \pm 90.92^{\mathrm{a}}$ & $331.67 \underset{\mathrm{abc}}{ \pm} 44.73$ & $3428.00 \pm 346.34^{b}$ \\
\hline \multirow{4}{*}{ Kidney } & Control & $18.77 \pm 3.51^{\mathrm{b}}$ & $10.83 \pm 0.54^{c}$ & $6.17 \pm 1.05^{b}$ & $22.93 \pm 0.40^{\mathrm{d}}$ & $5.43 \pm 1.25^{\mathrm{f}}$ & $10.60 \pm 0.28^{g}$ & $17.87 \pm 1.51^{\mathrm{d}}$ \\
\hline & $1 \mathrm{mg} / \mathrm{kg}$ & & $13.23 \pm 2.41^{\mathrm{bc}}$ & $23.87 \pm 6.33^{\mathrm{ab}}$ & $128.77 \underset{\mathrm{abcd}}{ \pm} 56.34$ & $149.33 \pm 19.01 \mathrm{de}$ & $\underset{\text { bcde }}{211.63 \pm 16.16}$ & $433.97 \pm 14.48^{\mathrm{d}}$ \\
\hline & $5 \mathrm{mg} / \mathrm{kg}$ & & $21.10 \pm 1.61^{\mathrm{bc}}$ & $56.93 \pm 13.70$ & $189.13 \pm \underset{a b c d}{ \pm} 35.01$ & $266.00 \pm 29.12^{\mathrm{cd}}$ & $336.57 \underset{\mathrm{ab}}{ \pm} 50.95$ & $1063.67 \pm 159.79^{c}$ \\
\hline & $10 \mathrm{mg} / \mathrm{kg}$ & & $36.30 \underset{\mathrm{abc}}{ \pm} 19.04$ & $103.87 \pm 59.37$ & $222.70_{\mathrm{ab}}^{ \pm} 79.69$ & $316.73 \pm 53.88^{b c}$ & $\underset{\text { abcd }}{252.93 \pm 75.78}$ & $4037.67 \pm 287.47^{\mathrm{a}}$ \\
\hline
\end{tabular}

Two-way ANOVA and Tukey' test were performed to compare the differences between groups and days of exposure. Values are shown as the mean $\pm \mathrm{SD}(n=3)$; Means in the same column with different letters $\left({ }^{\mathrm{a}-\mathrm{g}}\right)$ are significantly different $(p<0.05)$

Regarding the head kidney (Table 3), the accumulation of the 1,5 , and $10 \mathrm{mg} \mathrm{kg}^{-1}$ treatment groups were significantly higher $(p<0.05)$ on day $28(433.97 \pm 14.48,1063.67 \pm 159.79$, 
and $4037.67 \pm 287.47 \mu \mathrm{g} \mathrm{kg}^{-1}$, respectively) compared with the accumulation on days 1,4 , 7,14 , and 21 (Table 3). On day 1, no significant difference between the treatment groups and the control group was indicated $(p>0.05)$. On days $4,7,14$, and 21 , all treatment groups had significant differences compared with the control group $(p<0.05)$. On day 28 , all treatment groups had significant differences compared with the control group $(p<0.05)$; significant differences between the three treatment groups were also indicated $(p<0.05)$.

The accumulation of MeHg in the liver, head kidney, and muscle tissue gradually increased with increasing concentration and more days of exposure. Additionally, methylmercury exhibited significant accumulation on day 28 in all of the tissue samples of the treatment groups. The accumulation of $\mathrm{MeHg}$ in all the tissue samples was not significantly different at the start of the study. However, the accumulation increased gradually during the study and increased exponentially on day 28. At the conclusion of the study, the liver and head kidney accumulated more MeHg compared with the muscle tissue (Table 4).

\section{Discussion}

Organic mercury that is toxic to humans and animals is found in the forms of methylmercury and dimethylmercury. Methylmercury is a readily available form in nature that can accumulate in the food chain and be consumed by humans who eat fish [9]. Fish are usually exposed to $\mathrm{MeHg}$ through their feed (fish meal) and environmental water pollution [20]. The direct and indirect exposure of $\mathrm{MeHg}$ by fish can cause loss of appetite, brain damage, abnormal system development, cell necrosis, and the inhibition of respiratory burst activity, all of which affect the growth and immune response of fish and shellfish [21-24]. In this study, we evaluated data regarding the effect of MeHg exposure on nonspecific immune response and bioaccumulation in hybrid grouper.

Several studies have been conducted to examine MeHg toxicity on aquatic species cells in vitro. The SAF-1 cells from the marine gilthead seabream were immersed in various concentrations of $\mathrm{MeHg}$ and $\mathrm{Hg}$ for $24 \mathrm{~h}$; the concentration for $50 \%$ of maximal effect $\left(\mathrm{EC}_{50}\right)$ were $0.018 \mathrm{mM}(\approx 4.519 \mathrm{ppm})$ and $0.3 \mathrm{mM}(75.32 \mathrm{ppm})$, respectively [25]. Similarly, the HGST-BR green turtle brain cell line was exposed to $5 \mu \mathrm{M}$ of $\mathrm{MeHg}$ and $\mathrm{HgCl}$; cell viability in such exposure was 49\% and 69\%, respectively [26]. According to ISO 10993-5, a cell viability value that is $<70 \%$ of the blank (control) has a cytotoxic potential to the host cell [27]. In our study, the head kidney leukocytes were incubated with various concentrations of $\mathrm{CH}_{3} \mathrm{HgCl}$ to determine the maximum concentration to use in the dietary exposure. The leukocytes are directly exposed to methylmercury in in vitro experiment, and the cells will be damaged. Therefore, we first perform cell viability test to confirm whether leukocytes are still viability after $30 \mathrm{~min}$ of exposure to different concentrations of methylmercury, especially at high concentrations. Figure 1 illustrates that the viability of cells treated with 1000,5000 , and $10,000 \mu \mathrm{g} / \mathrm{L}$ was $82 \%, 39 \%$ and $32 \%$, respectively. Therefore, these results are in accordance with a relevant study that demonstrated that concentrations $>1000 \mu \mathrm{g} / \mathrm{L}$ have a toxic effect on fish. We conducted further research to determine the effect of $\mathrm{MeHg}$ on bioaccumulation and nonspecific immune responses such as phagocytic activity and the $\mathrm{O}_{2}{ }^{-}$production rate in hybrid grouper using concentrations of $\mathrm{MeHg}>1000 \mu \mathrm{g} / \mathrm{L}$.

Phagocytic activity is a crucial immune response in organisms for resisting foreign pathogens. After phagocytic cells engulf foreign pathogens or apoptotic cells, they produce reactive oxygen species such as $\mathrm{O}_{2}{ }^{-}$to remove the phagocytic substances [28,29]. In vitro approaches are used to observe the effects of $\mathrm{MeHg}$ exposure, particularly on nonspecific immune responses of aquatic species including phagocytic activity and $\mathrm{O}_{2}{ }^{-}$production rate. A relevant study demonstrated that Mediterranean mussel (Mytilus galloprovincialis) hemocytes incubated with $10^{-7}, 10^{-6}$, or $10^{-5} \mathrm{M}$ of $\mathrm{MeHg}$ had phagocytic rates that decreased with the increase of $\mathrm{MeHg}$ concentration and resulted in cell death [24]. Moreover, European sea bass (Dicentrarchus labrax) head kidney leukocytes that were incubated in $0.0005,0.005,0.05$, or $0.1 \mathrm{mM}$ of $\mathrm{MeHg}$ had phagocytic rates and respiratory burst activity that were significantly lower than those of that study's control group $(p<0.05)$ [22] 
Similarly, in our study, the phagocytic activity and $\mathrm{O}_{2}{ }^{-}$production rate of head kidney leukocytes decreased at concentrations $>500$ and $200 \mu \mathrm{g} / \mathrm{L}$, respectively. The phagocytic activity and $\mathrm{O}_{2}{ }^{-}$production rate decreased with the increase of $\mathrm{MeHg}$ concentrations. This is because the number of living cells is reduced, resulting in a reduced immune system response [27].

Hybrid groupers were exposed daily to $\mathrm{CH}_{3} \mathrm{HgCl}$ at various concentrations mixed in their diets to determine the nonspecific immune responses in the leukocytes of the head kidney. Head kidney leukocytes were used at several time points of sampling to evaluate the phagocytic activity and $\mathrm{O}_{2}{ }^{-}$production rate (Figures 4 and 5). The head kidney of fish plays a crucial role in the endocrine response to stress and the hematopoietic response [30]. This study demonstrated that $\mathrm{MeHg}$ exposure can reduce the phagocytic rate, phagocytic index, and $\mathrm{O}_{2}{ }^{-}$production rate in head kidney leukocytes of the hybrid grouper. This finding is similar to that of a relevant study that found that the phagocytic activity of Mya arenaria clams hemocytes decreased after exposure to mercury chloride and methylmercury at a concentration of $10^{6} \mathrm{M}$ in water for 28 days [31]. Nile tilapia (Oreochromis niloticus) exposed to mercury chloride at a concentration of $0.05 \mathrm{mg} / \mathrm{kg}$ for 21 days exhibited a decrease in the phagocytic index, phagocytic rate, and macrophage oxidative burst index compared with that study's control group [32]. Large yellow croaker (Pseudosciaena crocea) immersed in methylmercury at concentrations of $0.25,1$, and $4 \mu \mathrm{g} / \mathrm{L}$ for 30 days was significantly decreased superoxide dismutase activity compared with the control group [23]. Moreover, the sampling days of this study were designed according to the characteristics of the immune response. The immune reactions can be divided into acute and chronic reactions according to the time when the immune response occurs. Acute immune reactions occur on day 1,4 , and 7 in the experiment. The chronic reactions occur on day 14, 21 and 28 in the experiment. This result indicated $\mathrm{MeHg}$ affects the immunity of hybrid grouper very quickly, whether the concentration of $\mathrm{MeHg}$ is high or low. Thus, environmental stressors including $\mathrm{MeHg}$ exposure can affect the physiological state and overall welfare of fish.

Because few studies have focused on $\mathrm{MeHg}$ toxicity due to its bioaccumulation in hybrid grouper tissues after oral exposure, we developed a feeding study to better understand the bioaccumulation of $\mathrm{MeHg}$ in the liver, head kidney, and muscle tissue. A relevant study observed more $\mathrm{Hg}$ accumulation in muscle tissue than in the gills, liver, and gonads of perch (Perca fluviatilis) [33]. Similarly, according to Järv et al. [34], the highest concentration of $\mathrm{Hg}$ in perch (P. fluviatilis) was found in muscle tissue rather than the liver. By contrast, our study demonstrated that $\mathrm{MeHg}$ more significantly accumulated in the liver and head kidney than it did in the muscle tissue. This result was similar to that of a relevant study in which white sturgeon (Acipenser transmontanus) injected with 250,500 , or $1000 \mu \mathrm{g} / \mathrm{kg}$ of methylmercury chloride exhibited significant $\mathrm{Hg}$ accumulation in the intestines, followed in significance by the head kidney, liver, and muscle tissue [35]. Similarly, a study of olive flounder (Paralichthys olivaceu) fed with diets containing $\mathrm{MeHg}$ concentrations of 0 , $10,20,40$, or $160 \mathrm{mg} / \mathrm{kg}$ for 8 weeks indicated that $\mathrm{MeHg}$ accumulated primarily in the head kidney, followed in significance by the liver and gill tissues [13]. These results are in accordance with the findings in our study. The bioaccumulation of heavy metal is related to detoxification mechanisms and metabolism [36]. In marine mammals' livers, MeHg can be transformed into inorganic mercury, which is a less toxic form of mercury. When inorganic mercury is combined with metallothionein, the toxicity of mercury to organisms can be reduced [37]. However, high concentrations of mercury are still harmful to organisms. Pathological aberrations in the liver and head kidney tissues observed in histopathology of the Nile tilapia (O. niloticus) after $50 \mathrm{mg} / \mathrm{kg} \mathrm{Hg}$ exposure have been discovered [38]. Bioaccumulation be an enormous increase between days 21 and 28 which would possibly suggest systems are overwhelmed and $\mathrm{Hg}$ cannot be eliminated. However, this experiment analyzed the biological hazards and accumulation of $\mathrm{MeHg}$ to fish under different doses and exposure times. The results indicate that hybrid grouper significantly accumulated 
$\mathrm{MeHg}$ in the liver and head kidney rather than the muscle tissue and higher concentrations and more exposure days resulted in more significant accumulation.

Taken together, cell viability in vitro indicated that exposure to a concentration of $\mathrm{MeHg}$ exceeding $1000 \mu \mathrm{g} / \mathrm{L}$ have a toxic effect on cells, which decreases cell viability. This result correlates with the decreasing immune response at higher concentrations of $\mathrm{MeHg}$ exposure, which reduces the biological function of phagocytosis, causes cell death, and ultimately leads to a decline in fish immunity. The detoxification and metabolism activity in the liver and head kidney may become disturbed, and this disturbance may result in higher bioaccumulation of MeHg.

\section{Conclusions}

The initial study was evaluated the methylmercury exposure of hybrid grouper head kidney leukocytes in vitro subjected to different concentrations of $\mathrm{MeHg}$. By treating head kidney leukocytes in MeHg solution, we found that $\mathrm{MeHg}$ is an pollutant that causes a decrease in cell viability and nonspecific immune response such as phagocytic rate and superoxide anion production rate. During foodborne of exposure, we have also demonstrated that $\mathrm{MeHg}$ exposure can decrease the phagocytic rate, phagocytic index, and superoxide anion production rate. After dietary exposure to $\mathrm{MeHg}$ for 28 days, hybrid grouper significantly accumulated $\mathrm{MeHg}$ in the liver and head kidney rather than the muscle tissue. The cumulative concentration of each organ was positively correlated with the experimental concentration and exposure time. Therefore, this result correlates with the decreasing immune response at higher concentrations of $\mathrm{MeHg}$ exposure, which reduces the biological function and may relate to the liver and head kidney's detoxification and metabolism mechanism resulting in the increased accumulation of MeHg.

Author Contributions: Conceptualization and methodology, H.-C.C.; Writing—review and editing, and methodology, H.-T.H.; Writing—original draft preparation, N.-R.D.; investigation, H.-H.H.; formal analysis, B.-Y.C.; methodology, Z.-H.L.; methodology, M.-C.L.; methodology, P.-T.L.; investigation, Y.-S.W.; methodology, Y.-J.L.; supervision, F.-H.N. All authors have read and agreed to the published version of the manuscript.

Funding: This research was funded by the Council of Agriculture, Executive Yuan, R. O. C. (110AS6.2.1-FA-F6).

Institutional Review Board Statement: This study were performed in accordance with the Guide for Animal Use Protocol of the Institutional Animal Care and Use Committee (IACUC) of National Taiwan Ocean University, Approval No: 105063.

Informed Consent Statement: Not applicable.

Data Availability Statement: The authors confirm that the data supporting the findings of this study are available within the article.

Acknowledgments: The authors especially thank the editors and anonymous reviewers for their thoughtful comments.

Conflicts of Interest: The authors declare that they have no known competing financial interests or personal relationships that may influence the work reported in this paper.

\section{References}

1. FAO. The State of World Fisheries and Aquaculture 2020: Sustainability in Action. Available online: https://www.fao.org/ documents/card/en/c/ca9229en/ (accessed on 17 November 2021).

2. Che Ismail, C.-Z.; Koh, I.; Md sheriff, S. Cryopreservation of spermatozoa on grouper species: A review. Rev. Aquac. 2018, $12,26-32$.

3. Afero, F.; Miao, S.; Perez, A.A. Economic analysis of tiger grouper Epinephelus fuscoguttatus and humpback grouper Cromileptes altivelis commercial cage culture in Indonesia. Aquac. Int. 2009, 18, 725-739. [CrossRef]

4. Fan, B.; Yang, S.; Wang, L.; Chen, X.; Liu, X.; Zhang, Y.; Li, S.; Zhang, H.; Meng, Z.; Lin, H. Hybridization of tiger grouper (Epinephelus fuscoguttatus +) $\mathrm{x}$ giant grouper (Epinephelus lanceolatus or $^{7}$ ) using cryopreserved sperm. Cryobiology 2020, 95, 84-89. [CrossRef] [PubMed] 
5. Ching, F.F.; Othman, N.; Anuar, A.; Shapawi, R.; Senoo, S. Natural spawning, embryonic and larval development of F2 hybrid grouper, tiger grouper Epinephelus fuscoguttatus $\times$ giant grouper E. lanceolatus. Int. Aquat. Res. 2018, 10, 391-402. [CrossRef]

6. Chen, Y.-S.; Hsu, C.-Y. Ecological considerations of cage aquaculture in Taiwan. J. Fish. Soc. Taiwan 2006, 33, 139-146.

7. Zhang, Y.; Chu, C.; Li, T.; Xu, S.; Liu, L.; Ju, M. A water quality management strategy for regionally protected water through health risk assessment and spatial distribution of heavy metal pollution in 3 marine reserves. Sci. Total Environ. 2017, 599-600, 721-731. [CrossRef] [PubMed]

8. Gu, Y.-G.; Lin, Q.; Huang, H.-H.; Wang, L.-G.; Ning, J.-J.; Du, F.-Y. Heavy metals in fish tissues/stomach contents in four marine wild commercially valuable fish species from the western continental shelf of South China Sea. Mar. Pollut. Bull. 2017, 114, 1125-1129. [CrossRef]

9. Gochfeld, M. Cases of mercury exposure, bioavailability, and absorption. Ecotoxicol. Environ. Saf. 2003, 56, 174-179. [CrossRef]

10. Jinadasa, B.; Jayasinghe, G.; Pohl, P.; Fowler, S.W. Mitigating the impact of mercury contaminants in fish and other seafood-A review. Mar. Pollut. Bull. 2021, 171, 112710. [CrossRef]

11. Miao, X.; Hao, Y.; Tang, X.; Xie, Z.; Liu, L.; Luo, S.; Huang, Q.; Zou, S.; Zhang, C.; Li, J. Analysis and health risk assessment of toxic and essential elements of the wild fish caught by anglers in Liuzhou as a large industrial city of China. Chemosphere 2020, 243, 125337. [CrossRef]

12. Zhong, W.; Zhang, Y.; Wu, Z.; Yang, R.; Chen, X.; Yang, J.; Zhu, L. Health risk assessment of heavy metals in freshwater fish in the central and eastern North China. Ecotoxicol. Environ. Saf. 2018, 157, 343-349. [CrossRef]

13. Raihan, S.M.; Moniruzzaman, M.; Park, Y.; Lee, S.; Bai, S.C. Evaluation of Dietary Organic and Inorganic Mercury Threshold Levels on Induced Mercury Toxicity in a Marine Fish Model. Animals 2020, 10, 405. [CrossRef]

14. Jang, J.-W.; Lee, S.; Lee, B.-J.; Hur, S.-W.; Son, M.-H.; Kim, K.-W.; Kim, K.-D.; Han, H.-S. A comparative study of effects of dietary mercuric chloride and methylmercury chloride on growth performance, tissue accumulation, stress and immune responses, and plasma measurements in Korean rockfish, Sebastes schlegeli. Chemosphere 2020, 260, 127611. [CrossRef] [PubMed]

15. Awasthi, A.; Rathore, G.; Pradhan, P.K.; Rebello, S.C.; Khan, M.Y.; Lakra, W.S. Isolation and characterization of head kidney derived macrophages of Labeo rohita. J. Environ. Biol. 2014, 35, 949-954. [PubMed]

16. Chang, C.S.; Huang, S.L.; Cheng, S.; Cheng, S.N. Innate immune responses and efficacy of using mushroom beta-glucan mixture (MBG) on orange-spotted grouper, Epinephelus coioides, aquaculture. Fish Shellfish Immun. 2013, 35, 115-125. [CrossRef] [PubMed]

17. Domínguez-Borbor, C.; Chalén-Alvarado, B.; Rodríguez, J.A. A simple in vitro method to evaluate the toxicity of functional additives used in shrimp aquaculture. MethodsX 2018, 5, 90-95. [CrossRef] [PubMed]

18. Yue, F.; Pan, L.; Xie, P.; Zheng, D.; Li, J. Immune responses and expression of immune-related genes in swimming crab Portunus trituberculatus exposed to elevated ambient ammonia-N stress. Comp. Biochem. Physiol. Part A Mol. Integr. Physiol. 2010, 157, 246-251. [CrossRef]

19. Rotllant, J.; Parra, D.; Peters, R.; Boshra, H.; Sunyer, J.O. Generation, purification and functional characterization of three C3a anaphylatoxins in rainbow trout: Role in leukocyte chemotaxis and respiratory burst. Dev. Comp. Immunol. 2004, 28, 815-828. [CrossRef]

20. Xu, X.; Wang, W.-X. Mercury exposure and source tracking in distinct marine-caged fish farm in southern China. Environ. Pollut. 2017, 220, 1138-1146. [CrossRef] [PubMed]

21. Morcillo, P.; Esteban, M.A.; Cuesta, A. Mercury and its toxic effects on fish. AIMS Environ. Sci. 2017, 4, 386-402. [CrossRef]

22. Morcillo, P.; Cordero, H.; Meseguer, J.; Esteban, M.; Cuesta, A. In vitro immunotoxicological effects of heavy metals on European sea bass (Dicentrarchus labrax L.) head-kidney leucocytes. Fish Shellfish Immunol. 2015, 47, 245-254. [CrossRef]

23. Wu, F.; Huang, W.; Liu, Q.; Xu, X.; Zeng, J.; Cao, L.; Hu, J.; Xu, X.; Gao, Y.; Jia, S. Responses of Antioxidant Defense and Immune Gene Expression in Early Life Stages of Large Yellow Croaker (Pseudosciaena crocea) Under Methyl Mercury Exposure. Front. Physiol. 2018, 9, 9. [CrossRef] [PubMed]

24. Parisi, M.G.; Pirrera, J.; La Corte, C.; Dara, M.; Parrinello, D.; Cammarata, M. Effects of organic mercury on Mytilus galloprovincialis hemocyte function and morphology. J. Comp. Physiol. B 2021, 191, 143-158. [CrossRef] [PubMed]

25. Morcillo, P.; Esteban, M.Á.; Cuesta, A. Heavy metals produce toxicity, oxidative stress and apoptosis in the marine teleost fish SAF-1 cell line. Chemosphere 2016, 144, 225-233. [CrossRef] [PubMed]

26. Tong, J.; Wang, Y.; Lu, Y. In vitro evaluation of inorganic and methyl mercury mediated cytotoxic effect on neural cells derived from different animal species. J. Environ. Sci. 2016, 41, 138-145. [CrossRef] [PubMed]

27. ISO 10993-5:2009(E); Biological evaluation of medical devices-Part 5: Tests for in vitro cytotoxicity. ISO: Geneva, Switzerland, 2009. Available online: http:/ / nhiso.com/wp-content/uploads/2018/05/ISO-10993-5-2009.pdf (accessed on 17 November 2021).

28. Esteban, M.; Cuesta, A.; Chaves-Pozo, E.; Meseguer, J. Phagocytosis in Teleosts. Implications of the New Cells Involved. Biology 2015, 4, 907-922. [CrossRef]

29. Uribe-Querol, E.; Rosales, C. Phagocytosis. In Reference Module in Biomedical Sciences; Elsevier: Amsterdam, The Netherlands, 2021.

30. Tort, L. HORMONAL RESPONSES TO STRESS I Impact of Stress in Health and Reproduction. In Encyclopedia of Fish Physiology; Farrell, A.P., Ed.; Academic Press: San Diego, CA, USA, 2011; pp. 1541-1552.

31. Fournier, M.; Pellerin, J.; Clermont, Y.; Morin, Y.; Brousseau, P. Effects of in vivo exposure of Mya arenaria to organic and inorganic mercury on phagocytic activity of hemocytes. Toxicology 2001, 161, 201-211. [CrossRef] 
32. El-Boshy, M.E.; El-Ashram, A.M.; Abdelhamid, F.M.; Gadalla, H.A. Immunomodulatory effect of dietary Saccharomyces cerevisiae, beta-glucan and laminaran in mercuric chloride treated Nile tilapia (Oreochromis niloticus) and experimentally infected with Aeromonas hydrophila. Fish Shellfish Immunol. 2010, 28, 802-808. [CrossRef]

33. Łuczyńska, J.; Paszczyk, B.; Łuczyński, M.J. Fish as a bioindicator of heavy metals pollution in aquatic ecosystem of Pluszne Lake, Poland, and risk assessment for consumer's health. Ecotoxicol. Environ. Saf. 2018, 153, 60-67. [CrossRef]

34. Järv, L.; Kotta, J.; Simm, M. Relationship between biological characteristics of fish and their contamination with trace metals: A case study of perch Perca fluviatilis L. in the Baltic Sea. Proc. Est. Acad. Sci. 2013, 62, 193-201. [CrossRef]

35. Huang, S.S.-Y.; Strathe, A.B.; Fadel, J.G.; Lin, P.; Liu, T.-Y.; Hung, S.S.O. Absorption, distribution, and elimination of graded oral doses of methylmercury in juvenile white sturgeon. Aquat. Toxicol. 2012, 122-123, 163-171. [CrossRef]

36. Garnero, P.L.; Monferran, M.V.; González, G.A.; Griboff, J.; de los Ángeles, B.M. Assessment of exposure to metals, As and Se in water and sediment of a freshwater reservoir and their bioaccumulation in fish species of different feeding and habitat preferences. Ecotoxicol. Environ. Saf. 2018, 163, 492-501. [CrossRef] [PubMed]

37. Ikemoto, T.; Kunito, T.; Tanaka, H.; Baba., N.; Miyazaki., N.; Tanabe., S. Detoxification mechanism of heavy metals in marine mammals and seabirds: Interaction of selenium with mercury, silver, copper, zinc, and cadmium in liver. Arch Environ. Contam. Toxicol. 2004, 47, 402-413. [CrossRef]

38. Ayyat, M.S.; Ayyat, A.M.N.; Abd El-Latif, K.M.; Hessein, A.A.A.; Al-Sagheer, A.A. Inorganic mercury and dietary safe feed additives enriched diet impacts on growth, immunity, tissue bioaccumulation, and disease resistance in Nile tilapia (Oreochromis niloticus). Aquat. Toxicol. 2020, 224, 105494. [CrossRef] [PubMed] 